\title{
The Industrial Determinants of \\ Transnational Solidarity: Global \\ Interunion Politics in Three Sectors
}

\author{
Mark Anner \\ Pennsylvania State \\ Ian Greer \\ Cornell University \\ Marco Hauptmeier \\ Cornell University \\ Nathan Lillie \\ University of Helsinki \\ Nik Winchester \\ Cardiff University
}

\begin{abstract}
This article compares forms of labour transnationalism in three industrial sectors: motor manufacturing, maritime shipping and clothing and textile manufacturing. In each case, unions engage in very different transnational activities to reassert control over labour markets and competition. As institutions of transnational cooperation deepen, unions continue to struggle with competitive tensions (worker to worker and union to union) which vary from one industry to another.

KEYWORDS: motor industry; shipping; clothing; transnational union strategy; global framework agreements

\section{Introduction}

Increased global competition undermines union power by weakening control over labour market competition. Unions sometimes counter this threat by cooperating across national boundaries. Despite an explosion of interest in transnational union activities, there are few systematic comparisons across sectors. This article compares examples of transnational union cooperation in the motor vehicle, maritime shipping and clothing and textile industries. Unions adopt different kinds of international strategies, we argue below, because of (1) varying manifestations of worker-to-worker and union-to-union competition and (2) varying pre-existing traditions and practices of transnational regulation.
\end{abstract}

Of the three cases presented below, national patterns of worker representation retain the greatest importance in 
motor manufacturing, because unions continue to have a solid core of members with strong industrial leverage around a few corporate power centres. Pressures derive from management practices such as outsourcing and benchmarking, which have increased intra-firm competition. Where unions have responded through transnational cooperation, they have built out from strong local and national positions. They have constructed stable, firm-centred transnational relationships around European Works Councils (EWCs) and World Works Councils (WWCs). The firm-based character of these structures, however, shifts the focus of cooperation away from addressing global inter-firm competition. Local and national interests infuse the behaviour of transnational bodies, which seek to structure, rather than attenuate, inter-plant competition.

In maritime shipping, we find global sectoral collective bargaining developing in the context of a globalized regulatory framework. Under the flag of convenience (FOC) system of ship registration, employers may hire workers from any country to work anywhere in the world. Global competition occurs in a labour market segmented by craft and nationality, between unions and individuals seeking work in a denationalized labour market. Unions have been able to assert influence over this global labour market by building on pre-existing practices of transnational regulation and by disrupting crucial links in the production chain, mainly ports, enabling global collective bargaining to attenuate wage competition.

In clothing manufacturing, unions in the global North have not been able to prevent the exodus of jobs to the global South. Competition between North and South has gradually given way to a South-South competitive dynamic. Northern garment unions, such as the US-based Union of Needletrades, Textiles and Industrial Employees (UNITE), have aided organizing campaigns in the global South through consumer pressure in the North; but because employers responded by changing locations when factories unionized, they instead developed campaigns to organize less mobile textile-related industries at home. Labour transnationalism remains a matter of sporadic campaigning rather than ongoing organization.

This article discusses the state of the research on transnational labour competition and cooperation; sketches the push-and-pull factors which explain recent developments in global interunion politics; and examines three cases in terms of patterns of labour cooperation, competition and pre-existing transnational regulation.

Our cross-industry comparison is an attempt to unify threads of research on labour transnationalism based primarily on single-industry case studies. Notably, work on transnational union strategies in motor manufacturing has focused on EWCs and WWCs (Hancke, 2000; Zagelmeyer, 2000); in maritime shipping on global bargaining and industrial action (Koch- Baumgarten, 1998; Lillie, 2004; Northrup and Rowan, 1983); and in clothing and textiles on consumer campaigns, corporate codes and organizing (Anner, 2000; Miller, 2004). These differing research designs reflect the diverse manifestations of a common phenomenon, namely, cross-border union cooperation. In order to carry out a contextualized comparison of what may seem to be 'apples and oranges' (Locke and Thelen, 1995), we define each case in terms of the sector's actual level of union organization. Accordingly, we examine a specific German motor-manufacturing firm, the global collective bargaining structure of maritime shipping, and the shifting international strategy of a national apparel 
union in the USA.

Each case study is based on personal observation of the events described, press reports, academic literature and interviews with local, national, and international union officials, works councillors, managers and other employer representatives. Data collection was carried out by the authors in Europe, the USA and Latin America from 1997 to 2004.

\section{Global Markets and Global Regulation}

Globalization represents a shift of capitalism to a new geographic scale, challenging national trade unions. In his classic study of the rise of national unions in the USA, Commons (1909) argued that unions expanded in line with the extension of product markets. Ulman (1955) elaborated on this thesis, pointing out that this development, in the USA at least, was fragmented and incomplete. While many unions indeed did expand to national scope, some did not, and those that failed tended to remain weak and marginal labour market actors. Ulman showed that specific features of competition, such as the need to organize a mobile workforce, influenced the ability of local unions to cooperate, and therefore their ability to develop national institutions.

Likewise, cross-national cooperation is structured by competition. Today's national unions face a mismatch between the scale of globalizing labour markets and their own national organization. While managements within the same transnational corporation coordinate their industrial relations strategies (Marginson and Sisson, 2002), workers in most industries remain tied to local labour markets (Cox and Mair, 1988). However, local bargaining is increasingly driven by management efforts at transnational benchmarking. From the perspective of national sectoral or conglomerate unions, this creates an uneven playing field, especially when intensified cross-border competition leads local unions into concession bargaining (Tuckman and Whittall, 2002). The globalization of capital may, as a result, translate into localized worker unrest rather than the creation of a global labour movement (Silver, 2003). Internationalization leads, not to convergence or homogenization of IR practices and bargaining outcomes, but rather a growth in inter- and intra-sectoral differentiation within countries (Katz and Darbishire, 1999).

Competitive threats are not the only factors shaping labour transnationalism; opportunities also play an important role. Tarrow (2001), for example, cites 'political opportunity structures' to explain the domestic and international strategies of actors. Tarrow (1994: 85-9) defines political opportunity structure as a set of signals that make new kinds of action plausible to actors, including the opening of access to power, shifting of alignments, availability of influential allies, and cleavages among elites. Some of the sources of leverage mentioned below, such as strong, soli- daristic port unions, also provide industrial leverage, which can supplement or replace 'political' opportunities as avenues for union influence. The transnational political opportunities on which we focus result from private or quasi-public global regulation (Cutler et al., 1999). Regulatory powers and responsibilities, once primarily exercised by national governments, increasingly derive from supranational institutions and private organizations. These new structures smooth the functioning of the global capitalist economy, for example by resolving collective action dilemmas, and are created to suit the needs of a particular pattern of capitalist competition (Jessop, 2002).

These new inter-, trans-, and supranational regulatory structures can be regional or global, and at firm or industry 
levels, with implications for the opportunity structures that shape transnational interunion politics. Amoore (2002) considers firms not only as agents of globalization, but also as actors which create the spaces in which new contests over forms and structures of globalization occur. As such, we conceptualize spaces both with and around firms, such as European and global worker representation, supply chains and corporate codes of conduct, and standard industry practices in production processes and quality, as new terrains of struggle. Within these spaces, actors shift between local, national, and global strategies. For example, the efforts of unions to deal with European integration highlight their continuing national embeddedness. EWCs provide opportunities for transnational union networking, but are also fora for the expression of the competitive interests of nationally situated unions, works councillors and managers within firms (Tuckman and Whittall, 2002; Whittall, 2000).

\section{Labour Transnationalism: Forms, Push Factors and Pull Factors}

How do unions deal with the pressures and opportunities of globalization? Forms of cooperation differ according to the role of the relevant Global Union Federation (GUF), the degree of institutionalization of cooperation, the degree to which national worker organizations control the process and the susceptibility of cooperation to conflicts of interest between participating national unionists. They include network- and institution-building at globally consolidating motor vehicle firms, global collective bargaining in the maritime shipping industry and sporadic consumer campaigns in the textile and garment industry. This variation conditions what cooperating unions accomplish: global wage minima (shipping); coordinated local responses to restructuring (car manufacturing); or failed campaigns, followed by retreat and new, different campaigns (garments and textiles). Why do unions respond in such diverse ways to globalization?

As national strategies, such as protectionist trade policies or nationalist consumer campaigns (Frank, 1999), have shown their limits, push factors, or varying forms of intensified cross-border worker-to-worker competition, have emerged. The structure of competition varies according to the power relations within and between firms, the geographical scale and segmentation of the labour market, and the specific techniques of switching locations and workforces. In motor manufacturing, managers of unionized firms have pitted in-plant worker representatives against each other, usually citing pressures from low-cost competition. In maritime shipping, shipowners have created a de facto open global labour market by switching their ships to flags of convenience, intensifying competition between individual workers and nationalities. In the clothing industry, labels and retailers have put immense price-cutting pressure on manufacturers, who in turn have pitted groups of workers against each other with the threat of capital flight. These differences condition the problems that emerge and the solutions cooperating unions find plausible.

Complementing the push from global competition are pull factors: supportive structures at local, national and international levels that provide unions with opportunities and make certain kinds of cooperation plausible. These opportunities include pre-existing transnational coordination structures such as EU-mandated EWCs, a strong and unionized workforce around the industry's power centre, leverage points in the value-adding chain and access to global political and regulatory infrastructures. In German car firms and in the global maritime industry, a transnational opportunity structure external to the labour movement has helped unions institutionalize their international contacts. 
Without such an infrastructure, as in US motor manufacturing and the textile and garment industry, transnational union relations remain a matter of sporadic meetings and campaigns.

\section{Motor Manufacturing}

Labour transnationalism in the global motor industry, to the extent that it takes the form of regular meetings to influence employer policies, occurs within transnational firms. This is partly because large companies have raised the issue of cooperation by pitting local workforces against each other in their drive for cost-cutting and new production methods. On the other hand, opportunities also play a role, since worker representatives in the firms' home countries have, in some cases, borrowed from the rules of national industrial relations systems and European directives in their international strategies. At German car firms, EWCs function as jumping-off points for broader global coordination.

The sector's GUF, the International Metalworkers' Federation (IMF), has more than 200 affiliates in 100 countries, representing more than 25 million metalworkers. It advises trade unionists at the company level on organizing meetings and negotiating transnational forms of worker participation (Rub, 2002). It also helps formulate international framework agreements, in which transnational corporations agree to abide by specified labour standards. Works councillors in German-based firms, most of whom are members of IG Metall, play a leading role in building such transnational structures. In the USA, the United Automobile Workers (UAW), by contrast, engages with international partners only sporadically, via meetings of the IMF automobile working group. Brazilian car workers, who are represented by several unions, have few levers at home to force continued local production, and have therefore sought partners abroad. At German firms, Brazilian unionists have received help from works councils in the firms' home country; at US firms, they have lacked such assistance.

German works councils provide the institutional foundations for stable and effective actors within transnational networks. They have acted to influence production location decisions, for example by bargaining through EWCs. At General Motors (GM), the EWC, chaired by the head of the German joint works council, responded to the company's 1999 restructuring with simultaneous demonstrations throughout Europe, resulting in an agreement preventing forced redundancies. When Ford split off its parts plants in 1999, the EWC, also chaired by a German works councillor, responded by negotiating EU-wide guarantees, including a catalogue of orders for the now nominally independent supplier. In 2003, the EWC agreed with the latter a detailed package of in-plant concessions and a plant closure moratorium affecting the UK, France and Germany.

Works councillors have also led the way in global cooperation. For example, the central works council at DaimlerBenz fostered closer ties with unionists at the troubled, volume-carmaker Chrysler after the 1998 merger. The World Employees Committee (WEC), established shortly after the merger with advice from the IMF, became a forum where worker representatives would meet annually to exchange information with each other and with management. The WEC (with representatives from Germany, the USA, Canada, Brazil, South Africa and Spain) negotiated a framework agreement, known as the corporate 'Code of Social Responsibility', covering both DaimlerChrysler and its suppliers. Organizers in Turkish and Brazilian supplier plants used the code to bring pressure from DaimlerChrysler on their employers; several supplier companies lost their contracts because of violations. In addition, the works council and IG Metall took the 
unprecedented step of inviting UAW President Steve Yokich onto the merged company's supervisory board.

Establishing workplace representation is a central concern of US and Brazilian trade unionists, since managers have much more leeway than their German counterparts in avoiding union representation. While Brazilian unionists have turned to colleagues in Germany, UAW officials have relied on strong relations with core firms for leverage over suppliers. After the merger, for example, Mercedes managers at the Alabama plant called off anti-union campaigning, and the UAW won organizing victories at DaimlerChrysler's recently purchased Freightliner plants in North Carolina. DaimlerChrysler managers have also assisted the UAW in overcoming the anti-union strategies of first-tier suppliers that have grown up around northern assembly plants.

As Brazilian workers have struggled to maintain production orders and win new investment, they have strengthened their ties to Germany. At Volkswagen's Sao Bernardo plant, the union (Central Unica dos Trabal- hadores or CUT) has developed reciprocal relations with the Volkswagen (VW) works council, including a mutual pledge not to undertake strike-breaking work. German works councillors gave the Brazilians some crucial negotiating assistance when, in November 2001, the firm announced more than 3000 layoffs. After a three-day strike and failed negotiations with local management, CUT representatives travelled to Wolfsburg, where works councillors assisted them in obtaining new production orders. Brazilian unionists at Ford lacked a similar strategic partnership with the UAW, however. For example, in 1998 they negotiated a five-year layoff moratorium with management in Detroit, without coordination with the UAW. The CUT has sought a more strategic relationship with the UAW to address outsourcing, modular production and new human resource management practices.

Thus at DaimlerChrysler and Volkswagen, the works councils representing workers at the core operations of the parent company have supported stable transnational linkages, devoting staff resources to organizing meetings and finding willing partners in the leadership of their Brazilian colleagues. The UAW, by contrast, is more reluctant to build transnational structures, preferring to solve its problems domestically and undertaking international work on an ad hoc basis as crises and campaigns arise.

Why do worker representatives in the car assembly industry institutionalize their international cooperation at company rather than sectoral level? Cost-cutting in the motor industry does not yet entail a significant shift of employment away from the global North; companies prefer to produce close to major consumer markets, albeit in both high- and lowwage zones. Within these regions, top managers have imposed systematic comparisons between sites of work and demanded painful changes in exchange for new investment. Corporations have implemented a dual process of downsizing and reorganization of the remaining production capacity, enforcing competition between establishments (Hancke, 2000; Mueller and Purcell, 1992). In an industry with excess productive capacity, most unionists believe that only the most efficient plants and firms can survive.

In the USA, Ford, GM and DaimlerChrysler dominate the industry. After low-cost competition caused severe crises throughout the 1980s, the big three have reduced costs by increasing the proportion of parts made by outside firms and low-wage sites in Mexico, separating off parts plants as new firms and implementing lean production throughout their 
operations. Combined with systematic performance and process monitoring mechanisms, these measures have put pressure on the national UAW to allow a decline in the number of well-paid jobs and a rise in the number of lower-paid jobs.

Germany's car workers are also no longer safe, whether at luxury producers such as DaimlerChrysler or volume producers such as VW or Ford. Both industry segments have engaged in highly visible concession bargaining: lean production systematic comparisons, the growth of nearby low-wage production, and vertical disintegration. Works councils have negotiated pacts to cut costs and save jobs (Rehder, 2003; Zagelmeyer, 2000), including a wave of plantlevel concessions in 2004. Competition within or between firms, facilitated by technical standardization and the high volumes necessitated by increased capital intensity (Mueller and Purcell, 1992) has led management to make new demands.

Brazil's motor industry is the most vulnerable of the three. Final assembly production is entirely owned by foreign firms, including Ford, GM, DaimlerChrysler and VW. Car producers, who invested in Brazil to reap the benefits of a rapidly growing domestic consumer market predicted in the 1950s and 1960s, have been disappointed by the lack of growth. New firms are locating outside the core industrial district of the greater Sao Paulo region, where car workers' wages and union density are much higher than elsewhere in the country. This steady loss of jobs in brownfield sites has forced these unions into concession bargaining. Motor producers are also increasingly turning to modular production, especially in greenfield sites, which has further fragmented the workforce and weakened unions (Anner, 2004).

Yet why is the UAW less interested than its Brazilian or German counterparts in building transnational structures? Transnational union relationships are pulled by the national industrial relations systems of the globalizing firm's home country. In the large German firms, works councillors have played a leading role in the construction of transnational cooperation, initially through action in the 1980s against apartheid and dictatorship and usually driven by leftist works councillors and church groups; Brazilian unionists have used their contacts with German works councillors from the days of dictatorship as leverage to retain work orders. The 1994 EWC Directive has provided a further impetus for a weaker version of transnational networking between workers from many countries. As the 'host country' argument suggests, this has resembled a transnational extension of German codetermination practices (Streeck, 1997).

The UAW operates in an environment hostile to labour transnationalism. Its officials focused during the 1980s and 1990s primarily on fighting imports and developing national mechanisms to participate in company decision-making. Partnership with management occurs within a set of rules and resources established in national pattern bargaining with the big three, involving union representatives in the details of benchmarking, outsourcing, and downsizing decisions. The UAW has countered management's international 'whipsawing' strategies more with in-firm partnership than systematic cross-border solidarity.

Compared to their German and US counterparts, Brazilian car workers have far less access to central management. They lack both a strong national organization and large domestic producers. Even as local bargaining and mobilization remained the core of Brazilian motor union strategy, pre-existing networks with German works councillors developed in 
the 1980s became invaluable tools for the challenges of the 1990s.

The motor industry provides, in some ways, models for effective international coordination within the firm. In German companies, works councillors have, to a significant degree, used the EWC Directive to address the challenges of intensified competition. The links between unionists in different firms are not, however, strong enough to take wages out of competition industry-wide. The result is an ethos of 'fair competition' and bargaining over the distribution of concessions.

\section{Maritime Shipping}

In the maritime shipping industry, labour transnationalism has taken the form of an enforcement regime for global wage minima. Like unions in the motor industry, maritime unions are able to use industrial leverage to control the labour market; but they also cooperate with one another at the global sectoral level, and no one national actor dominates. Following decades of internal negotiation, the International Transport Workers Federation (ITF) which claims a membership of more than 600 unions representing in excess of five million transport workers in more than 140 countries, has displaced national unions as the decisive wage negotiator. Unlike other GUFs, the ITF is independently funded: under its collective agreements, employers contribute into the Seafarers' International Assistance, Welfare and Protection Fund, receipts to which were estimated at $£ 18$ million in 2003.

Building on pre-existing global regulatory practices over a highly mobile workforce and in response to a hypercompetitive environment, maritime unionists have established global wage standards. The ITF represents seafarers not primarily as national citizens with wage norms based on local economic conditions, but rather as members of a global profession with universally certified and recognized skills. According to this logic, seafarers have the right to a minimum wage scaled according to skill rather than national origin. This is backed up by an 'industrial' campaign to influence and exert control over the globalized FOC labour market. Initially, the ITF attempted to resist the FOC system, but industrial action is now targeted to attenuate competition between low-wage labour-supplying countries and enforce global wage minima.

This cornerstone of ITF policy requires a negotiated order between affiliates, based on consensus. Although unions are under pressure to compete to win jobs for their members by supplying attractively priced labour to employers, they almost universally agree that some agreed wage minimum must exist. ITF agreements, enforced through port inspections and the threat of industrial action, set minimum wage standards, overtime rates, benefits, rudimentary staffing scales and standards of accommodation and safety. In April 2002, ITF agreements covered 5996 out of 20,096 registered FOC vessels (ITF, 2003: 27).

Employers have resisted the application of the ITF wages in various ways, ultimately without success. During the early stages of the union's campaign in the 1970s, they evaded ITF agreements through double bookkeeping schemes and other deceptions (Northrup and Rowan, 1983). During the 1980s, under the auspices of the International Shipping Federation (ISF), they began to coordinate legal and political action in an attempt to restrict the scope of ITF activity, with limited success (Johnsson, 1996). Finally, in the 1990s, in response to tightening enforcement of ITF wage rates, a group 
of shipping companies formed the International Maritime Employers' Committee (IMEC), which in the end accepted wage minima in exchange for some influence over their levels (Lillie, 2004).

Central to IMEC's bargaining strategy is the exploitation of differences in wage-level preferences within the union camp. Consensus within the ITF membership is precarious, given the continuing threat of competition from seafarers outside the ITF labour cartel, especially from China. Tensions over the wage rate came to a head during negotiations in late 2001, when the Filipino union, the Associated Marine Officers' and Seamen's Union of the Philippines (AMOSUP), dissented from the ITF consensus. In 2000, the ITF and IMEC had agreed in principle to a benchmark of US\$1200 per month for an Able Seaman (the standard job category in ITF agreements), with an annual US\$50 rise in the years 2001-04. AMOSUP officials, after endorsing the agreement, argued that the proposed rate increase placed Filipino seafarers at a competitive disadvantage relative to other labour-supplying states, especially China (Lloyd's List, 2001).

The ITF dealt with this tension by taking AMOSUP's dissent seriously, since its own legitimacy and efficacy depended on the support of key labour-supplier unions. Although AMOSUP stressed the need to temper wage rises, it did not question the need for standard global wages, since it too depends for its power on a global wage-bargaining system. The ITF took an 'evidence-based' approach, commissioning an independent analysis of the economic impacts of the proposed rise. Following the report, ITF affiliates agreed to defer the increase for a year, ensuring the continued support of labour-supplier unions. Although some affiliates, such as the Danish ratings' union, criticized this decision (Lloyd's List, 2002), the ITF managed to uphold the fragile consensus underpinning global wage bargaining, at least in the short run.

Why, despite employer opposition and conflicts of interest within the labour camp, did global bargaining become possible? The FOC regime has sparked hyper-globalization of the seafaring labour market. Since the 1950s, a growing number of states have set up FOC registers 'with the specific aim of offering shipowners a registration service, often as a means of earning revenue for the flag state' (Stopford, 1997: 434). The use of FOCs has grown substantially: in 2000, more than 50 percent of the world's tonnage was so registered (Lloyd's Register, 2000). Shipowners who use FOCs are free from national regulations (such as those mandating that crew members share the nationality of the flag of the ship), they can hire workers from around the globe and organize blends of nationalities across job categories as they see fit.

Ships crewed and flagged in the same country are thus becoming a thing of the past (Alderton et al., 2004). Highly skilled and trained officers still often come from northern countries, while the less skilled ratings with lower pay are overwhelmingly from the global South. Seafarers from western industrialized states account for 27 percent of senior officers, 12 percent of junior officers, and 5 percent of ratings; 37 percent of ratings are Filipino, compared to 24 percent of junior officers and 11 percent of senior officers (SIRC, 2004). Three-quarters of vessels report two or more nationalities on board; 20 percent report four or more. Although there is no clear pattern, there is a significant trend towards western European senior officers combined with single-nationality, mainly Filipino, ratings (Lane et al., 2002: 22-30). Because work contracts usually last the length of a voyage, seafarers lack long-term dependence on any particular firm, favouring sectoral rather than company-level union structures. Contracts vary in length: a western European officer typically works three months on and three months off; Filipino ratings usually have nine-month contracts separated by longer periods of 
unemployment (Amante, 2004).

Global competition is only part of the explanation for sectoral union cooperation. As in the motor industry, the flows of work provide opportunities for highly disruptive local action, but shipping also has a long and developing tradition of private and public global regulation. Global actors in the regulatory system include the ITF, employer groups such as IMEC and the ISF, national and regional port state authorities, and UNassociated bodies such as the International Maritime Organization and the International Labour Organization. These have complemented the FOC deregulatory regime with regulation covering such issues as skill certification and safety (Dirks, 2001). Global regulation can be seen as a response to the negative impacts of a regime which allows shipowners systematically to externalize many costs, for example by incorporating single ships as offshore companies in FOC countries (Alderton and Winchester, 2002).

Political opportunities at the global sectoral level are complemented by opportunities for unions to exert direct industrial pressure on employers, because of the interdependence of transportation linkages. Despite the complexity of ship ownership and registration, unions can still apply pressure on employers by interrupting the flow of cargo. The ITF relies on solidaristic industrial action by dockworker unions, who can stop the unloading of ships; it ties dock workers into its global strategy through a transnational network of unionists, who monitor collective agreements and mobilize actions against non-compliant employers.

Seafaring has thus developed global wage standards because of political opportunities provided by global public and quasi-public regulation and because of strong opportunities for industrial contention. This pattern is suited to the establishment of uniform wage minima. Unlike clothing, the transnational campaigns involved have coalesced into a global structure. Unlike motor manufacturing, the structure is defined by sector rather than by firm.

\section{Clothing Manufacturing}

In textiles and garments, international solidarity has shifted from manufacture to retail, as the industry has abandoned the global North while South-South competition has made organizing in the developing world difficult. As in shipping, unions in the textile and garment industry face highly mobile capital; but they have neither found the leverage nor developed the transnational structures to counter capital flight. Transnational labour activists sought originally to use pressure from consumers in the North, based on product image and human rights concerns, to establish bargaining at production locations in the South. This kind of campaigning has been encouraged by the growth of corporate retail marketing strategies concerned with demonstrating corporate social responsibility, creating a space for contestation based around retail supply chains (Christopherson and Lillie, 2005). By the 2000s, however, after a number of incidents showed that unionization merely resulted in capital flight, Northern unionists began to turn away from organizing overseas production, and instead merged with other unions or moved into other sectors domestically, or both. Because of this, international campaigning has shifted to a transatlantic focus around efforts to organize retail and distribution workers in the North. Southern unions in textile and clothing have remained unstable and largely without influence.

The industry GUF, the International Textile Garment and Leather Workers' Federation (ITGLWF), claims 216 affiliated unions in 106 countries, representing 10 million workers. Since most of these workers are in poor countries, dues 
collection is very low and almost all ITGLWF funding for international organizing comes from project-specific donations. It has worked with national unions in the USA and Europe in a largely unsuccessful strategy to support organization in Central America and the Caribbean. However, the ITGLWF has not developed an independent global organizing strategy, perhaps partly because it lacks resources. Instead, national unions with specific transnational organizing projects have taken the lead, often relying heavily on alliances with nongovernmental organizations (NGOs) to coordinate consumer pressure in the North with organizing effort in the South (Anner, 2000). UNITE, in particular, has been very active in such transnational organizing campaigns. European unions have also been involved through supporting consumer mobilization by the Clean Clothes Campaign (CCC), and through direct financial and technical support.

UNITE's strategy to organize workers in the Caribbean and Central America yielded short-lived first contracts and Pyrrhic victories. In cooperation with Dominican unionists in the early 1990s, UNITE helped to unionize nine factories, covering 4000 workers. Following these successes, it began to coordinate its transnational organizing efforts through the ITGLWF, and loaned the federation a staff organizer. European unions, such as the Dutch federation FNV, also helped fund the project. In Honduras, with assistance from UNITE and the ITGLWF, local activists organized short work stoppages to pressure the company into accepting the union at Kimi, a Korean-owned factory (Frundt, 1998). By March 1999, the union negotiated a collective contract that raised wages and provided new benefits. In May 2000, however, the owners closed the plant, destroying the union. In 2001 in El Salvador, UNITE, the ITGLWF and US NGOs assisted workers at a Taiwaneseowned factory, Tainan. They provided organizing advice to the local union and coordinated a consumer campaign in the USA targeting The Gap, one of Tainan's major buyers. In 2002, the company announced it was closing the factory, citing lack of orders caused by the plant's unionization.

In the wake of these failures, UNITE and its European partners began to conclude that because of the extreme power imbalances in developing countries, direct organizing would not work, at least in the short term. Instead, textile unions in the North began shifting to strategies based more on organizational survival than on organizing the global industry. UNITE now focuses on workforces in locally bounded labour markets such as garment distribution centres, industry laundry facilities and retailers, where plant closure is not such a likely outcome of an organizing 'success'. International coordinated campaigning continues, but is now used to solicit support from European partners in local campaigns to organize transnational firms active in the USA, for example in gaining the help of French unions in organizing an Indianapolis clothing distribution centre owned by Brylene, a subsidiary of the French firm Pinault-Printemps- Redoute (the company also owns Gucci and Yves Saint Laurent).

Similarly, there has been a wave of mergers of clothing unions into more stable organizations. UNITE itself is the result of an important merger between competing unions in the 1990s. In 2004, it merged in turn with the Hotel and Restaurant Employees (HERE) to form UNITE HERE. This merger reflects an organizational rather than industrial logic, and has accompanied the shift of organizing efforts from production to distribution and retail. For similar reasons, European clothing unions have merged into larger unions: the German Gewerkschaft Textil und Bekleidung joined IG Metall in 1997 and analogous mergers have occurred in Sweden (1993), Austria (2000) and Finland (2004). Evidently, Northern clothing unions do not think there will be a sufficiently large group of clothing workers in their home countries to continue to 
support independent unions in the future.

Why have clothing union campaigns remained sporadic and relatively unsuccessful? Capital mobility resulting in cut-throat competition has played a central role, as organized workplaces in both the global North and South have lost the race for jobs. There are thousands of relatively small firms with minimal sunk costs in any given location and mobile equipment (sewing machines). Major Northern retailers and brand- named clothing corporations, or 'labels', have immense power in the marketplace, adopting a model of subcontracting which gives them the ability rapidly to shift the location of work at little cost. Subcontracting firms face stiff demands for cost reductions, which in turn creates strong incentives to keep wages low and production goals high: to 'sweat' the factory workforce. The distribution of power in this value chain contributes to concentration at the top end of the industry, forcing workers in widely dispersed geographical locations into direct cost competition with one another.

Unions in the North face declining employment levels, with the USA being particularly affected, while most production has moved to the global South (Anner, 2004). Despite the shift, one-fifth of the sector's workers remain in Europe, the USA and Japan, as a result partly of protectionism, partly of labour-management collaboration and, in Europe, partly of concentration in high-tech specialized textiles. However, more than 50 percent of the world's textile and garment workers are now in China and India (Dicken, 2003: 286). Among other East Asian countries, Thailand, Indonesia, the Philippines and South Korea have attracted the most jobs. The share of Central and South American producers in the global market is relatively small, although they play an important role for the US market. In addition to the movement of jobs from North to South, there is competition among southern locations to attract and maintain jobs.

While pressures on textile and garment unions have been much more disruptive than in car manufacturing or seafaring, the opportunities have been much weaker. Unlike in the motor industry, production, consumption and corporate control do not overlap spatially. Major retailers do not have large, unionized production workforces in their home countries, and they do not usually own the factories where their clothes are produced. Manufacturers can pursue a low-cost labour strategy, because it is easy to shift production somewhere else if the workforce should unionize, and because they often receive help from local or national governments in suppressing labour organizations.

Moreover, transnational institutions such as EWCs or WWCs have not been useful in this sector. Miller (2003: 206) finds that EWCs in the clothing industry 'are either poorly organized . . . or are removed from the interests of workers involved directly in production, because only marketing, design and distribution functions tend to remain in Europe'. Nor, unlike in the shipping industry, is there a clear locus for conducting transnational negotiations or potential leverage from strongly unionized groups elsewhere in the production chain. Textile and garment unions have had to seek other power resources, such as the image sensitivity of global retail chains and major brand-named products, and leveraging corporate and industry-level codes of conduct to assist organizing drives in otherwise hostile environments.

In sum, internationally coordinated union activity in the textile and garment sector has taken place with neither transnational institutional support nor strong national bases of unionization. Managers of the labels resolve these conflicts through arrangements with suppliers, consulting firms and occasionally NGOs, with minimal union involvement. For 
clothing unions, cataloguing the worst abuses and holding firms responsible has neither addressed the problem of capital mobility nor reduced labour market competition among production workers. Furthermore, the ITGLWF is weaker and more poorly funded than the either the ITF or the IMF. With little structural support or industrial leverage, international campaigns have remained susceptible to unstable relations between national unions and dependent on episodic overlaps of interest and consumer preferences.

\section{Discussion}

In each sector, national and local trade unionists fought to retain existing jobs, thereby accepting the logic of worker-to-worker competition. Whether these parochial interests frustrated international cooperation and how they shaped it, however, varies. The different productive and regulatory structures produce different sets of challenges and opportunities for unions, and consequently result in different types of union strategy.

In the motor industry, national interests matter a great deal. EWCs act as transnational opportunity structures that allow national actors to set up broader, global arenas. Because there are no EWCs in the USA, the UAW's international strategies are less developed than those of its German counterparts. While the first two global framework agreements were negotiated at VW and DaimlerChrysler, managers at Ford have independently established their own code of conduct. National and local trade unionists have been able to avoid hard compromises over global standards, since they are not absolutely necessary for organizational survival in the short term, except perhaps in Brazil. Transnationalism is only one part of the trade unionists' larger toolbox (mostly consisting of local, national and plant-level tactics) in dealing with capital mobility.

In contrast to this 'host' effect, the maritime case suggests that international cooperation can be more than an expression of local or national interests. In the shipping industry, a GUF mediates conflicts of national interest though global collective bargaining machinery. This leaves the power structures of national unions intact, but also produces common pressure for wage floors, both in the North and the South. National unions have accepted a loss of authority to the ITF in order to prevent a complete loss of control over working conditions. The denationalization of wage bargaining has not erased parochial interests; instead, the ITF resolves them by negotiations between unions. It thus prevents employers from playing off groups of workers against each other to the same extent as in the motor and clothing industries.

The clothing case, however, shows that there is no guarantee that global unionism will fill the void resulting from the decline of local and national unions. International campaigns depend on fleeting convergences of interests with international partners to target specific firms. Rather than establishing transnational bargaining, unions are abandoning the industry and organizing less mobile clothing-related industries. Unions are so weak that monitoring is most often left to specialist firms or NGOs, in contrast to the motor or maritime sectors, where unions negotiate and enforce the agreements. Transnational strategies remain important, since the largest employers in the new sectors are large, transnational corporations. The level and consistency of leverage unions have generated through transnationally coordinated industrial action and consumer pressure, however, have not been sufficient to give them influence over the 
location of production.

Clothing and motor unions face competition between sites of production, and therefore are defending much more locally defined interests than in maritime shipping. In both industries, internationally cooperating unions win, at most, 'fair competition' between sites of work, rather than global collective bargaining agreements to take wages out of competition. In principle, the transnational extension of unionism has the justification of improving working conditions, wages and union strength in less developed countries while lessening downward pressure and 'whip-sawing' in the North. Motor and garment unions, however, have not accomplished this goal, because of inter-plant competition for jobs and the lack of sectorally structured opportunities for influence.

\section{Conclusion}

In all three cases, unions have engaged in transnational activities in an effort to reassert control over labour markets and competition. Only in maritime shipping have they built industry-level structures to do this. These structures enjoy solid support within the ITF union coalition, although their future is threatened by low-wage competition from China. In motor manufacturing, unions exert strong, locally based influence, and have constructed viable transnational institutions regulating competition between the production sites of specific firms. They continue, however, to be handicapped by the insularity of some national unions and the lack of a strategy relevant to inter-firm competition. In clothing, unions have lost local control and have failed to regain it at the global level where competition occurs.

Broad, encompassing transnational actors such as GUFs could, in principle, define and implement a global union strategy. However, with the exception of the ITF and its FOC campaign, GUFs remain underfunded and dependent on the resources and initiatives of national affiliates (Muller et al., 2003). The maritime case shows that competition does not necessarily prevent transnational union cooperation from developing into wage bargaining. Competition can frustrate cooperation, but it also motivates it. The international projects of motor and textile unions may create the basis for new, unforeseeable opportunities, which could allow unions to counter the debilitating effects of competition and build a truly global unionism.

\section{ACKNOWLEDGEMENTS}

This article has benefited from discussions at Transatlantic Social Dialogues in Ithaca and Brussels, in March 2003, May 2004 and May 2005. In particular, Ginny Couglin, Helmut Lense, Torsten Muller, Wolf-Jurgen Roeder and Stefan Rub provided valuable feedback. We would also like to thank the three anonymous reviewers and Richard Hyman for their useful comments. Funding for field research was provided by the Social Science Research Council, the Andrew W. Mellon Foundation, the People's Education Foundation of Finland, the German Academic Exchange Service, the Max Planck Institute for the Study of Societies, the New York State School of Industrial and Labor Relations, the Ford Foundation, the Center for Advanced Human Resource Studies and the US Department of Education.

\section{REFERENCES}

Alderton, T. and Winchester, N. (2002) 'Globalization and De-regulation in the Maritime Industry', Marine Policy 26: 35- 
43.

Alderton, T., Bloor, M., Kahveci, E., Lane, A.D., Sampson, H., Thomas, M., Obando-Rojas, B., Winchester, N., Wu, B. and Zhao, M. (2004) The Global Seafarer: Living and Working Conditions in a Globalised Industry. Geneva: ILO.

Amante, M. (2004) Labour Market Report: Philippines. London: Clarkson Research.

Amoore, L. (2002) 'Work, Production and Social Relations: Repositioning the Firm in the Global Political Economy', in J. Harrod and R. O'Brien (eds) Global Unions: Theory and Strategies of Organized Labour in the Global Political Economy, pp. 29-48. London: Routledge.

Anner, M. (2000) 'Local and Transnational Campaigns to End Sweatshop Practices', in M. Gordon and L. Turner (eds) Transnational Cooperation among Labour Unions, pp. 238-55. Ithaca, NY: ILR Press.

Anner, M. (2004) 'Between Solidarity and Fragmentation: Labor Responses to Globalization in the Americas', PhD Dissertation. Ithaca, NY: Cornell University.

Christopherson, S. and Lillie, N. (2005) ‘Neither Global Nor Standard:

Corporate Strategies in the New Era of Labor Standards', Environment and Planning-A 37(11): 1919-38.

Commons, J.R. (1909) 'American Shoe Makers 1648-1895', Quarterly Journal of Economics 26: 39-83.

Cox, K. and Mair, A. (1988) 'Locality and Community in the Politics of Local Economic Development', Annals of the Association of American Geographers 78(2): 307-25.

Cutler, A., Haufler, V. and Porter, T. (1999) Private Authority and International Affairs. Albany, NY: SUNY Press.

Dicken, P. (2003) Global Shift: Transforming the World Economy, 4th edn. New York: Guilford Press.

Dirks, J. (2001) Internationales positives Regulieren in der Handelsschifffahrt im Kontext der Globalisierung: Eine Untersuchung der STCW 95 Konvention. Munster: LIT Verlag.

Frank, D. (1999) Buy American: Untold Story of Economic Nationalism.

Boston, MA: Beacon Press.

Frundt, H. (1998) Trade Conditions and Labour Rights: U.S. Initiatives,

Dominican and Central American Responses. Gainesville: University Press of Florida.

Hancke, B. (2000) 'European Works Councils and Industrial Restructuring in the European Motor Industry', European Journal of Industrial Relations 6(1): 35-59.

ITF (2003) The International Transport Workers' Federation Flags of Convenience Campaign Report 2001/02. London: ITF. Jessop, B. (2002) 'Time and Space in the Globalization of Capital and their Implications for State Power', Rethinking Marxism 14(1): 97-117.

Johnsson, L. (1996) Funny Flags: ITF's Campaign - Past, Present and Future. Stockholm: Utbildningsforlaget Brevskolan. 
Katz, H. and Darbishire, O. (1999) Converging Divergences: Worldwide Changes in Employment Systems. Ithaca, NY: Cornell University Press.

Koch-Baumgarten, S. (1998) 'Trade Union Regime Formation under the Conditions of Globalization in the Transport Sector: Attempts at Transnational Trade Union Regulation of Flag-of-Convenience Shipping', International Review of Social History 43: $369-402$.

Lane, T., Obando-Rojas, B., Wu, B. and Tasiran, A. (2002) Crewing the International Merchant Fleet. Redhill: Lloyd's Register-Fairplay.

Lillie, N. (2004) 'Global Collective Bargaining on Flag of Convenience Shipping', British Journal of Industrial Relations 42(1): 47-67.

Lloyd's List (2001) 21 December.

Lloyd's List (2002) 14 March.

Lloyd's Register (2000) World Fleet Statistics. London: Lloyd's Register.

Locke, R. and Thelen, K. (1995) 'Apples and Oranges Revisited: Contextualized Comparisons and the Study of Comparative Labor Politics', Politics and Society 23(3): 337-67.

Marginson, P. and Sisson, K. (2002) 'European Dimensions to Collective Bargaining: New Symmetries within an Asymmetric Process?', Industrial Relations Journal 33(4): 332-50.

Miller, D. (2003) 'The Limits and Possibilities of European Works Councils in the Context of Globalisation: Experiences in the Textile, Clothing and Footwear Sector', in I. Fitzgerald and J. Stirling (eds) European Works Councils: Pessimism of the Intellect, Optimism of the Will? pp. 198-210. London: Routledge.

Miller, D. (2004) 'Preparing for the Long Haul: Negotiating International Framework Agreements in the Global Textile, Garment and Footwear Sector', Global Social Policy 4(2): 215-39.

Mueller, F. and Purcell, J. (1992) 'The Europeanization of Manufacturing and the Decentralization of Bargaining: Multinational Management Strategies in the European Automobile Industry', International Journal of Human Resource Management 3(1): 15-34.

Muller, T., Platzer, H. and Rub, S. (2003) ‘Globalisierung und gewerkschaftliche Internationalisierung: Zur Politik der Global Union Federations', WSI Mitteilungen 56(11): 666-72.

Northrup, H. and Rowan, R. (1983) The International Transport Workers' Federation and Flag of Convenience Shipping. Philadelphia: University of Pennsylvania.

Rehder, B. (2003) Betriebliche Bundnisse fur Arbeit in Deutschland: Mitbestimmung und Flachentarif im Wandel. Frankfurt: Campus.

Rub, S. (2002) World Works Councils and Other Forms of Global Employee Representation in Transnational Undertakings: 
A Survey. Dusseldorf: Hans-Bockler-Stiftung.

Silver, B. (2003) Forces of Labor: Workers' Movements and Globalization Since 1870. New York: Cambridge University Press.

SIRC (Seafarers International Research Centre) (2004) Global Labour Market Database. Cardiff: SIRC.

Stopford, M. (1997) Maritime Economics. London: Routledge.

Streeck, W. (1997) 'Neither European nor Works Councils: A Reply to Paul Knutsen', Economic and Industrial Democracy 18(2): 325-37.

Tarrow, S. (1994) Power in Movement: Social Movements, Collective Action and Politics. Cambridge: Cambridge University Press.

Tarrow, S. (2001) 'Transnational Contention: Contention and Institutions in International Politics', Annual Review of Political Science 4(1-2): 1-20.

Tuckman, A. and Whittall, M. (2002) 'Affirmation, Games and Insecurity:

Cultivating Consent Within a New Workplace Regime', Capital and Class 76: 65-94.

Ulman, L. (1955) The Rise of the National Trade Union: The Development and Significance of its Structure, Governing Institutions, and Economic Policies. Cambridge, MA: Harvard University Press.

Whittall, M. (2000) 'The BMW European Works Council: A Cause for

European Industrial Relations Optimism?', European Journal of Industrial Relations 6(1): 61-83.

Zagelmeyer, S. (2000) 'Brothers in Arms in the European Car Wars:

Management-Labour Pacts in the Context of Regime Competition', MPIfG Working Paper 00/2. 